\title{
Genetic diversity assessment among Corema album (L.) D. Don (Ericaceae) genotypes based on ISSR markers and agro-morphological traits
}

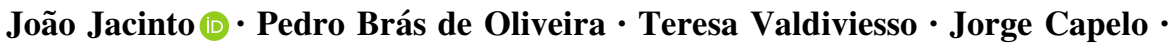 \\ Pedro Arsénio · Filomena Nóbrega
}

Received: 21 May 2019/Accepted: 21 October 2019/Published online: 24 October 2019

(C) Springer Nature B.V. 2019

\begin{abstract}
Corema album (L.) D. Don is the only species of the genus Corema growing naturally on sand dunes throughout the Atlantic coast of the Iberian Peninsula, noted for the white coloured berries and nutritional value. The lack of information on genetic studies of the species is one of the most limitations for the establishment of this species as a new culture. Thus, this study focuses on the assessment of the genetic diversity based on inter-simple sequence repeats (ISSR) molecular markers and morphological traits. Seventy-one female plants, from four different sampled sites, were evaluated using six ISSR loci and eight morphological traits. Fifty polymorphic loci were detected. The dendrogram based on the UPGMA method and the principal coordinate analysis classified the 71 C. album genotypes into distinct clusters. The
\end{abstract}

\section{J. Jacinto}

Instituto Superior de Agronomia, Universidade de Lisboa, Tapada da Ajuda, 1349-017 Lisbon, Portugal

J. Jacinto $(\bowtie)$ · P. Brás de Oliveira · T. Valdiviesso • J. Capelo · F. Nóbrega Instituto Nacional de Investigação Agrária e Veterinária, I.P. (INIAV), Unidade Estratégica de Sistemas Agrários e Florestais e Sanidade Vegetal, UEIS-SAFSV, Av. da República, Quinta do Marquês, 2780-157 Oeiras, Portugal e-mail: jmantunesj@gmail.com

J. Capelo · P. Arsénio

Linking Landscape, Environment, Agriculture and Food (LEAF), Instituto Superior de Agronomia, Universidade de Lisboa, Tapada da Ajuda, 1349-017 Lisbon, Portugal analyses revealed that accessions from the same geographical area were generally, but not entirely, clustered into the same group. Analysis of molecular variance was higher among populations, than within populations. The analysis of morphological traits revealed that there is no distinct separation among the $C$. album genotypes grown in different geographic areas. To our knowledge, this is the first study on the assessment of the genetic diversity in this species.

Keywords White crowberry - Genetic diversity · Inter-simple sequence repeat · Agro-morphological traits

\section{Introduction}

Corema album (L.) D. Don belongs to the Ericaceae family and occurs naturally on sand dunes of the Atlantic coast of the Iberian Peninsula (ssp. album), and in the Azores Islands on volcanic lava and ash fields (ssp. azoricum Pinto da Silva). Besides its great ecological importance (Guitián et al. 1997; Zunzunegui et al. 2006), its edible white berries have been highly appreciated and exploited (Oliveira and Dale 2012) due to the high nutritional value and important antioxidant properties. These berries contain high amounts of anti-oxidants, phenolic acids, flavonoids and low amounts of anthocyanins (León-González et al. 2013; Andrade et al. 2017b) and are also an 
important source of fibbers and sugars (Andrade et al. 2017a).

Despite the important properties with potential benefits on human health, this species is still poorly exploited from a commercial point of view, being still harvested from the wild without any cultivation. However, there is an increasing demand for berries with a distinct white colour. Therefore, the establishment of this species as a new crop with fruit of high quality for responding to consumer demands and exploring market opportunities is a challenge.

The characterization of DNA based-markers provides information on the genetic diversity and relationship both within a population (intragroup diversity) and among different populations (intergroup diversity) which provide useful knowledge for breeding selection (Agarwal et al. 2008). Inter-simple sequence repeat (ISSR) markers have shown great potential for assessing the genetic diversity of wild species and structuring of natural populations (Zietkiewicz et al. 1994; Ueno et al. 2015; Zoratti et al. 2015). The ISSR technique is simple, fast and has high reproducibility, low costs and no genome knowledge is need for its implementation (Reddy et al. 2002). These markers have also been used in genetic studies on Vaccinium populations, which also belong to the Ericaceae family (An et al. 2015; Debnath 2007, 2009; Gawroński et al. 2017; Yakimowski and Eckert 2008). For C. album, only a molecular approach using ISSR was carried out among male and female plants to identify a putative sex-specific marker (Nóbrega et al. 2016).

The present research work employs a survey conducted in wild populations along its distribution area for evaluation of genetic diversity using ISSR markers.

\section{Materials and methods}

Plant material and sampling sites

We sampled 20 female $C$. album plants drawn from four populations (Table 1) sited at different biogeographical units along the Atlantic coast of Portugal. For all plants, geographical coordinates were recorded using the global position system (GPS).

In all populations, the vegetation cover was dominated by C. album shrubs and Pinus pinaster Ait. was present further inland of the dune systems, except in Monte Clérigo. In Comporta and Meco, the populations were on the interface between the dunes and the pine woodland, whereas the population of the Duna de Quiaios was under the canopy of the pine woodland.

Molecular data

\section{DNA isolation and amplification}

Fresh and healthy leaves were ground to a fine powder in liquid nitrogen using pre-cooled mortar and pestle and then stored at $-80{ }^{\circ} \mathrm{C}$ until use for DNA extraction.

Total genomic DNA was isolated from approximately $100 \mathrm{mg}$ of leaf powder using the DNeasy Plant Mini Kit (QIAGEN, Hilden, Germany) following the manufacturer's instructions. The concentration of DNA was estimated with the NanoDrop 2000 UVVis Spectrophotometer (Thermo Fisher Scientific, Massachusetts, USA).

A set of 20 ISSR primers were screened. Of these, six primers were selected based on their reproducibility and levels of polymorphism and used for final analysis. Primers used with their respective sequences and annealing temperature were showed in Table 2.

PCR reactions were performed in a $25 \mu \mathrm{l}$ final volume of using the Promega GoTaq Flexi DNA Polymerase Kit (Promega, Madison, USA), containing $1 \mu \mathrm{l}$ template DNA, $5 \mu \mathrm{l}$ GoTaq Flexi PCR buffer, $1.5 \mathrm{mM} \mathrm{MgCl} 2,0.20 \mathrm{mM}$ each dNTPs, $1.25 \mathrm{U}$ GoTaq Flexi DNA Polymerase (Promega, Madison) and $0.4 \mu \mathrm{M}$ of each primer in a Biometra Tgradient thermocycler (Biometra, Gottingen, Germany), in a Biometra Tgradient thermocycler (Biometra, Göttingen, Germany) (Nóbrega et al. 2016).

Amplification profile consisted of an initial denaturation of $3 \mathrm{~min}$ at $94{ }^{\circ} \mathrm{C}$, followed by 40 cycles for $1 \mathrm{~min}$ at $94{ }^{\circ} \mathrm{C}, 1 \mathrm{~min}$ at the annealing temperature (Table 2), 2 min at $72{ }^{\circ} \mathrm{C}$ and a final extension for $10 \mathrm{~min}$ at $72{ }^{\circ} \mathrm{C}$. Amplicons were separated by electrophoresis at $5 \mathrm{~V} \mathrm{~cm}^{-1}$ in agarose gel (1.5\%) containing $0.5 \mathrm{~g} / \mathrm{mL}$ ethidium bromide and $1 \times \mathrm{TBE}$ running buffer.

In order to have a representative survey for the distribution area, 20 accessions by population were sampled, as described before.

However, the DNA from three plants from Meco, two from Monte Clérigo and four from Duna de 
Table 1 Origin (collection coordinates of $C$. album populations site) and geographical

\begin{tabular}{lll}
\hline Primer name & Sequence $\left(5^{\prime}-3^{\prime}\right)$ & Annealing temperature $\left({ }^{\circ} \mathrm{C}\right)$ \\
\hline UBC840 & $(\mathrm{GA})_{8}$ YT & 49 \\
UBC845 & $(\mathrm{CT})_{8}$ RC & 50 \\
UBC848 & $(\mathrm{CA})_{8}$ RG & 50 \\
UBC855 & $(\mathrm{AC})_{8}$ YT & 50 \\
UBC891 & HVH $(\mathrm{TG})_{7}$ & 50 \\
MR & GAGGGTGGCGGTTCT & 55 \\
\hline
\end{tabular}

\begin{tabular}{lll}
\hline Code & Origin & Coordinates latitude (N) longitude (W) \\
\hline $\mathrm{M}$ & Meco & $38^{\circ} 29^{\prime} 15^{\prime \prime} 9^{\circ} 11^{\prime} 02^{\prime \prime}$ \\
$\mathrm{C}$ & Comporta & $38^{\circ} 22^{\prime} 55^{\prime \prime} 8^{\circ} 48^{\prime} 06^{\prime \prime}$ \\
$\mathrm{MC}$ & Monte Clérigo & $37^{\circ} 20^{\prime} 29^{\prime \prime} 8^{\circ} 51^{\prime} 11^{\prime \prime}$ \\
$\mathrm{Q}$ & Duna de Quiaios & $40^{\circ} 13^{\prime} 52^{\prime \prime} 8^{\circ} 50^{\prime} 59^{\prime \prime}$ \\
\hline
\end{tabular}

Table 2 List of primers used for ISSR amplification, sequences and annealing temperatures

$(\mathrm{Y}=\mathrm{C}, \mathrm{T} ; \mathrm{R}=\mathrm{A}, \mathrm{G}$;

$\mathrm{H}=\mathrm{A}, \mathrm{C}, \mathrm{T} ; \mathrm{B}=\mathrm{C}, \mathrm{G}, \mathrm{T}$;

$\mathrm{V}=\mathrm{A}, \mathrm{C}, \mathrm{G} ; \mathrm{D}=\mathrm{A}, \mathrm{G}, \mathrm{T})$
Quiaios, was not able to get proper PCR amplification, showing reduced yields. Thus, although we aimed to analyse 80 accessions, due to low amplification quality, some samples had to be excluded and only 71 genotypes were included in the assessment of the genetic diversity.

\section{Morphological data}

A total of 10 quantitative phenotypic traits were assessed in detail, during flowering (March to May) and fruiting season (August and September) in all plants. The traits list included the most important leaf, flower and fruit features: plant volume, flower/inflorescences ratio, number of leaves per whorl, length of annual growths, branching number, number of fruits with more than $10.25 \mathrm{~mm}$ in diameter, number of fruits with diameter between 10.25 and $7.50 \mathrm{~mm}$, number of fruits with less than $7.50 \mathrm{~mm}$ in diameter, percentage of white fruits and fruit dry/fresh weight ratio.

From the 10 traits, only eight were used, for further analyses, as it was explained in the in the statistical analyses part of the morphological variation, due to colinearity among some of them and also to their agronomic relevance. Thus, number of fruits with diameter between 10.25 and $7.50 \mathrm{~mm}$ and with less than $7.50 \mathrm{~mm}$ were discarded.

\section{Statistical analyses}

Genetic diversity

The genetic diversity of four populations was analysed using six ISSR selected primers.

Scoring of ISSR amplification product sizes was carried out by considering only the clear and unambiguous bands. The results were transformed into a binary presence (1) - absence (0) matrix. Genetic diversity was estimated by three indexes calculated for each ISSR marker: the polymorphism information content (PIC) (Roldán-Ruiz et al. 2000), the resolving power (RP) (Prevost and Wilkinson 1999) and the marker index (MI) (Powell et al. 1996) and by the parameters: number of bands, number of polymorphic bands and percentage of polymorphic loci.

The data obtained by scoring the ISSR profiles of different primers were subject to cluster analysis using the $71 \times 71$ matrix of the Nei-Li dissimilarity coefficient (Nei and Li 1979) ran in the stats $\mathrm{R}$ package ( $\mathrm{R}$ Core Team 2013). The dendrogram was performed using UPGMA clustering method (Unweighted Pairgroup Method Analysis) by the factoextra R package (Kassambara and Mundt 2017). The genetic structure and the differences between populations were evaluated through a Principal Coordinate Analysis (PCoA) using the vegan $\mathrm{R}$ package (Oksanen et al. 2013). A hierarchical analysis of molecular variance (AMOVA) was also performed by using pegas $\mathrm{R}$ package (Paradis et al. 2018). 
Table 3 Genetic diversity estimates of $C$. album populations including NB: number of bands; NPB: Number of polymorphic bands; PPB: Percentage of polymorphic bands; PIC:
Polymorphism information content; MI: Marker index; RP: Resolving power and ISSR populations

\begin{tabular}{|c|c|c|c|c|c|c|c|c|c|c|}
\hline \multirow[t]{2}{*}{ Primers } & \multirow[t]{2}{*}{$\mathrm{NB}$} & \multirow[t]{2}{*}{ NPB } & \multirow[t]{2}{*}{ PPB } & \multirow[t]{2}{*}{ PIC } & \multirow[t]{2}{*}{ MI } & \multirow[t]{2}{*}{$\mathrm{RP}$} & \multicolumn{4}{|c|}{ ISSR populations } \\
\hline & & & & & & & $\begin{array}{l}\text { Meco } \\
(\mathrm{n}=17)\end{array}$ & $\begin{array}{l}\text { Comporta } \\
(\mathrm{n}=20)\end{array}$ & $\begin{array}{l}\text { Mt. Clérigo } \\
(\mathrm{n}=18)\end{array}$ & $\begin{array}{l}\text { Duna de Quiaios } \\
(\mathrm{n}=16)\end{array}$ \\
\hline $\begin{array}{r}\text { UBC } \\
840\end{array}$ & 6 & 6 & 100 & 0.34 & 9.04 & 17.24 & 10 & 13 & 7 & 7 \\
\hline $\begin{array}{r}\text { UBC } \\
845\end{array}$ & 10 & 10 & 100 & 0.35 & 7.69 & 10.06 & 13 & 9 & 12 & 9 \\
\hline $\begin{array}{r}\text { UBC } \\
848\end{array}$ & 8 & 7 & 87.5 & 0.30 & 6.93 & 6.89 & 14 & 13 & 9 & 6 \\
\hline $\begin{array}{r}\text { UBC } \\
855\end{array}$ & 8 & 8 & 100 & 0.37 & 8.00 & 12.37 & 14 & 12 & 13 & 3 \\
\hline $\begin{array}{r}\text { UBC } \\
891\end{array}$ & 9 & 9 & 100 & 0.32 & 11.27 & 12.49 & 12 & 12 & 6 & 11 \\
\hline M 13 & 10 & 10 & 100 & 0.16 & 17.41 & 8.51 & 10 & 7 & 5 & 7 \\
\hline
\end{tabular}

Number of different ISSR profiles among populations and primers

\section{Morphological variability}

Kruskall-Wallis test among the four populations, at a significance level of $\alpha=0.05$, was performed in all traits assessed. A Fisher's post hoc test $(\alpha=0.05)$ for mean separation was also conducted. The agricolae $\mathrm{R}$ package (De Mendiburu 2019) was used.

In order to seek relations between variables in all plants of the four populations $(n=71)$, Spearman's correlation $(\alpha=0.05)$ was used from Hmisc R package (Harrell 2014).

A previous selection of the traits was made regarding their correlations and their agronomic interest. Eight traits were used to perform principal component analyses (PCA), with factoextra R package, in order to find which traits differentiate better each population (Kassambara and Mundt 2017).

A dissimilarity matrix was calculated from the eigen values extracted from the first three PCA axis, using the Mahanalobis distance, like it was performed in Pereira-Lorenzo et al. (2012). This was achieved by using StatMatch R package (D'Orazio and D'Orazio 2019). Dendrogram was built also using the UPGMA method by means of the factoextra $\mathrm{R}$ package (Kassambara and Mundt 2017). To evaluate the relationship between matrices of genetic and morphological traits dissimilarities the Mantel test's correlation, were calculated using the vegan R package (Oksanen et al. 2013).

\section{Results}

Genetic diversity

All the six ISSR primers produced distinct reproducible polymorphic banding patterns with a total number of 51 scorable bands, ranging from 6 to 10 bands per primer, with an average of 8 bands per primer (Table 3). Amplification products ranged from $500 \mathrm{bp}$ to $2.0 \mathrm{~kb}$.

The Polymorphism Information Content (PIC) values of the primers varied between 0.16 (primer M13) and 0.37 (primer UBC855) with an average of 0.31 . The highest Marker index (MI) was showed in primer M13 (17.41), with an average of 10.1 per primer. The highest resolving power was from UBC840 (17.24), with an average per primer of 11.26. Regarding ISSR banding profiles the genotypes from Meco and Comporta presented higher diversity than the genotypes from Monte Clérigo and Duna de Quiaios (Table 3).

The dendrogram issued from a cluster analysis based on 51 ISSR markers (Fig. 1). Five distinct clusters were identified. Cluster four consisted of 
Fig. 1 Dendrogram obtained with UPGMA method using the Nei and $\mathrm{Li}$ coefficient for 71 plants of the four populations $(\mathrm{r}=0.729)$

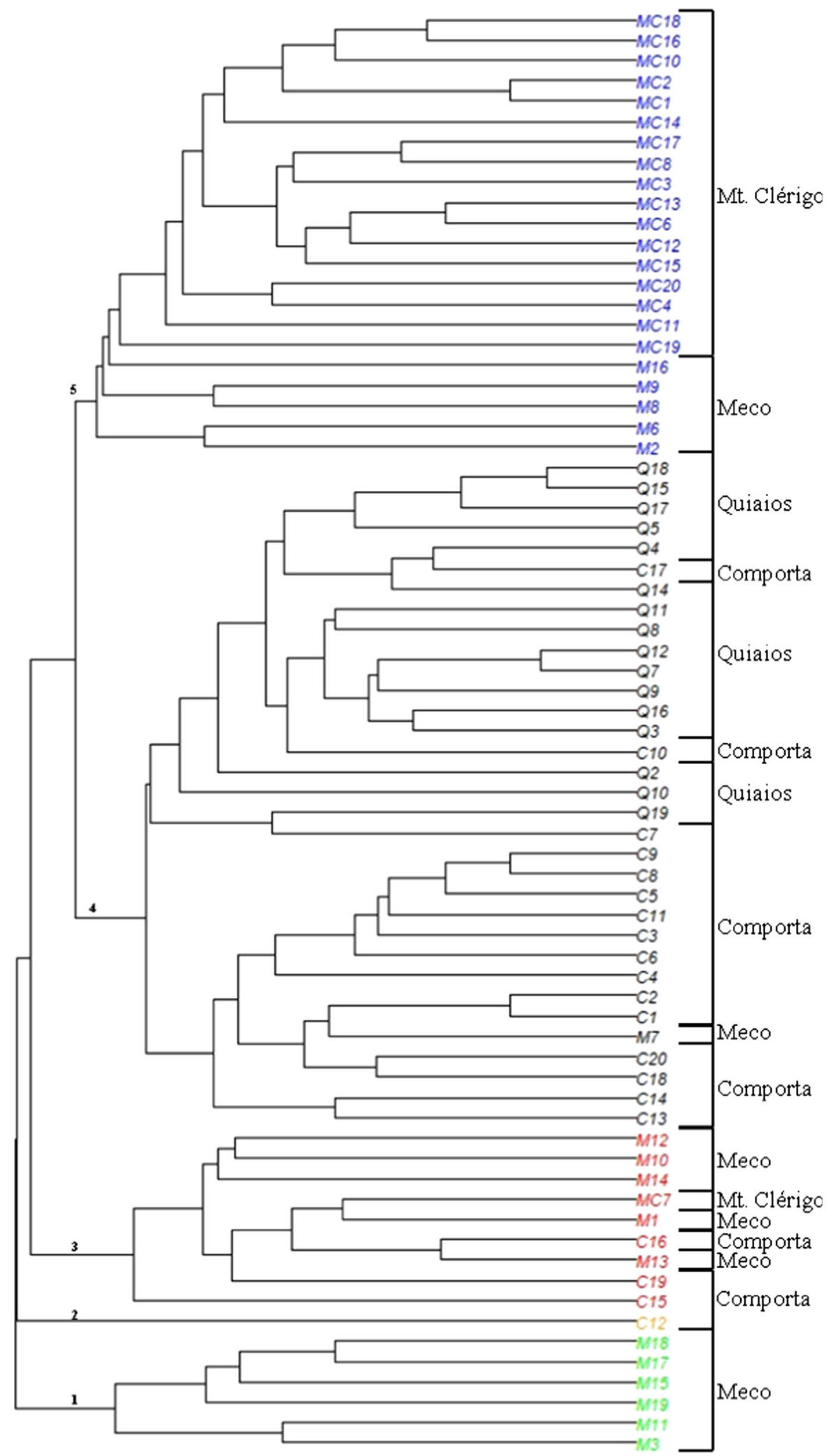




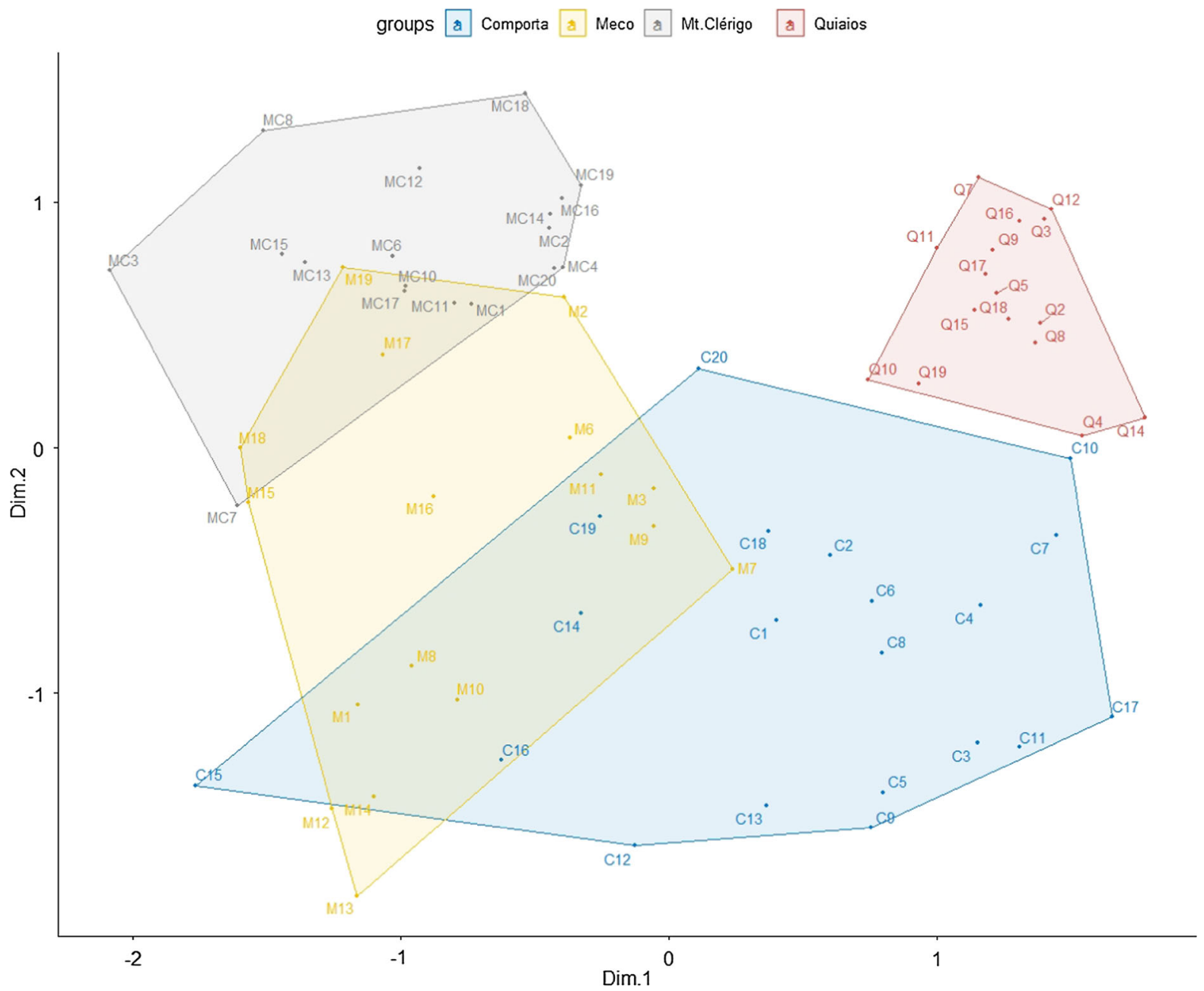

Fig. 2 Principal Coordinates Analyses (PCoA) of the molecular data, which explained $22 \%$ of the variation amongst populations

accessions from Duna de Quiaios and cluster five with the accessions from Monte Clérigo. Accessions from Meco were dispersed in all except cluster two and Comporta was dispersed in clusters one, two and three.

PCoA analysis performed on the ISSR Nei-Li dissimilarity matrix among all genotypes is presented in Fig. 2. Axis 1 and 2, contributed with $22 \%$ of the variation observed. Accessions from Duna de Quiaios, Comporta and Monte Clérigo were clearly discriminated. Accessions from Meco overlapped Monte Clérigo and the Comporta populations. Comporta was the most scattered population and Duna de Quiaios had a smaller group.

AMOVA analysis showed that the proportion of variation attributable to among populations was high $(62.40 \%)$ whereas only $37.6 \%$ occurred within populations.
Morphological variability

The Kruskal-Wallis test performed in the 10 morphological traits, showed significant differences among populations (Table 4). Vegetative traits were the ones that had more significant differences among the four sites. The number of fruits in each of the three classes was higher in Meco and Comporta, although no significant differences were showed in the two higher fruit classes. The percentage of white fruits was only significantly different in Monte Clérigo. The ratio of dry/fresh fruit weight was higher in Quiaios and lower in Comporta, which means that the relation pulp/seed size was higher in Quiaios.

Spearman's correlation showed higher significant correlations in the number of branches and number of fruits with diameter between 10.25 and $7.50 \mathrm{~mm}$, with 
Table 4 Summary table regarding morphological traits mean differences, in the four populations

\begin{tabular}{|c|c|c|c|c|c|c|c|c|}
\hline \multirow[t]{3}{*}{ Traits } & \multicolumn{8}{|c|}{ Populations } \\
\hline & \multicolumn{2}{|l|}{ Meco } & \multicolumn{2}{|l|}{ Comporta } & \multicolumn{2}{|c|}{ Monte Clérigo } & \multicolumn{2}{|l|}{ Quiaios } \\
\hline & $\begin{array}{l}\text { Average } \\
(n=17)\end{array}$ & $\pm \mathrm{SD}$ & $\begin{array}{l}\text { Average } \\
(n=20)\end{array}$ & $\pm \mathrm{SD}$ & $\begin{array}{l}\text { Average } \\
(n=18)\end{array}$ & $\pm \mathrm{SD}$ & $\begin{array}{l}\text { Average } \\
(n=16)\end{array}$ & $\pm \mathrm{SD}$ \\
\hline Plant volume $\left(\mathrm{m}^{3}\right)$ & $3.1 \mathrm{~b}$ & 1.67 & $6.9 \mathrm{a}$ & 4.36 & $1.9 \mathrm{c}$ & 1.21 & $1.9 \mathrm{c}$ & 1.25 \\
\hline Leaves per two whorls & $6.5 \mathrm{bc}$ & 0.87 & $7.1 \mathrm{ab}$ & 1.36 & $6.2 \mathrm{c}$ & 0.51 & $7.3 \mathrm{a}$ & 1.06 \\
\hline Length of annual growths $(\mathrm{cm})$ & $2.1 \mathrm{c}$ & 0.51 & $2.7 \mathrm{~b}$ & 0.82 & $1.3 \mathrm{~d}$ & 0.44 & $3.5 \mathrm{a}$ & 0.67 \\
\hline Average number of branches & $12.3 \mathrm{~b}$ & 2.56 & $12.1 \mathrm{~b}$ & 4.16 & $15.7 \mathrm{a}$ & 3.02 & $8.8 \mathrm{c}$ & 2.10 \\
\hline Flower/inflorescence ratio & $6.7 \mathrm{ab}$ & 1.10 & $7.4 \mathrm{a}$ & 1.62 & $6.2 \mathrm{~b}$ & 1.79 & $7.4 \mathrm{a}$ & 1.65 \\
\hline \multicolumn{9}{|l|}{ Number of fruits per class } \\
\hline$<10.25 \mathrm{~mm}$ & $12 \mathrm{a}$ & 15 & $27 \mathrm{a}$ & 27 & $7 \mathrm{a}$ & 6 & $1 \mathrm{a}$ & NA \\
\hline $10.25 \geq \mathrm{x}<7.5 \mathrm{~mm}$ & $135 \mathrm{a}$ & 144 & $109 \mathrm{a}$ & 73 & $90 \mathrm{a}$ & 54 & $24 \mathrm{~b}$ & 33 \\
\hline$\geq 7.5 \mathrm{~mm}$ & $131 \mathrm{ab}$ & 91 & $181 \mathrm{a}$ & 120 & $90 \mathrm{bc}$ & 81 & $67 \mathrm{c}$ & 39 \\
\hline White fruits (\%) & $62.2 \mathrm{a}$ & 23.11 & $51.1 \mathrm{a}$ & 23.17 & $24.7 \mathrm{~b}$ & 20.99 & $59.1 \mathrm{a}$ & 25.09 \\
\hline Dry/fresh fruit weight ratio & $0.22 \mathrm{~b}$ & 0.04 & $0.18 \mathrm{c}$ & 0.03 & $0.20 \mathrm{bc}$ & 0.03 & $0.24 \mathrm{a}$ & 0.04 \\
\hline
\end{tabular}

Fisher's post hoc test $(\alpha=0.05)$ was performed and significant differences between columns were marked with a different letter

the other variables (data not showed), therefore both traits were excluded to perform the Principal Component Analyses (PCA). The rest of the traits showed smaller or non significant correlations.

The first three axis of the PCA accumulated $62.1 \%$ of the trait variation (Fig. 3). In PC1, length of the annual growths, ratio of flowers per inflorescence and white fruit percentage had more influence in this axis (25.2\%). Plant volume, number of fruits with more than $10.25 \mathrm{~mm}$ in diameter and dry/fresh fruit weight, had a positive load in PC2 (24\% of the variation). Finally, in PC3 which accumulated $12.9 \%$ of the variation, was influenced by the number of fruits smaller than $7.5 \mathrm{~mm}$ in diameter and the number of leaves per two whorls.

Cluster analysis based on the Mahalanobis distance, calculated as dissimilarity measure between the 71 genotypes, from the standardized three first principal components (PCs), and clustered by UPGMA, and produced the dendrogram presented in Fig. 4. The morphological traits varied widely and the highest phenotypic diversity was observed in Comporta and Meco. However, this general distribution of the genotypes did not reflect the geographical origin.

Mantel test between the morphological and molecular dissimilarity matrices showed a low correlation $(\mathrm{r}=0.139 ; p=0.004)$.

\section{Discussion}

The genetic improvement of any crop is dependent on the utilization of well characterized wild relatives and breeding techniques. The assessment of genetic diversity is a requirement to select high yielding genotypes.

Fifty alleles were identified by six ISSR markers proving their ability to be used as polymorphic markers in $C$. album accessions. Although ISSR markers have been extensively used to assess genetic diversity, there are no reports in Corema genus, which include only two species. Thus, to our knowledge this is the first study on the assessment of the molecular genetic diversity in this species.

Regarding molecular data the clustering analyses showed that Meco and Comporta were the populations with more dispersed accessions in the dendrogram, which could lead to a higher genetic diversity compared to Monte Clérigo and Duna de Quiaios.

Both the PCoA analysis and phylogeny reconstruction based on ISSR markers reveals a clustering pattern consistent with geographical location and suggestive of response to environmental conditions variation. In fact, the PCoA analysis showed that the Comporta and Meco populations present a higher dispersion compared to other populations. This 
Fig. 3 Principal component analysis (PCA) showing the dispersion of the individual of the four populations sampled, as well as what were the traits that had the biggest influence on each population. $\mathrm{Vl}=$ Plant volume, $\mathrm{RFI}=$ flower/ inflorescences ratio, NLW = Number of leaves per two whorl, LAG = Length of annual growths, $\mathrm{BN}=$ Branching number, HFC $=$ Number of fruits with more than $10.25 \mathrm{~mm}$ in diameter, $\mathrm{PWt}=$ Percentage of white fruits, RP = fruit dry/fresh weight ratio

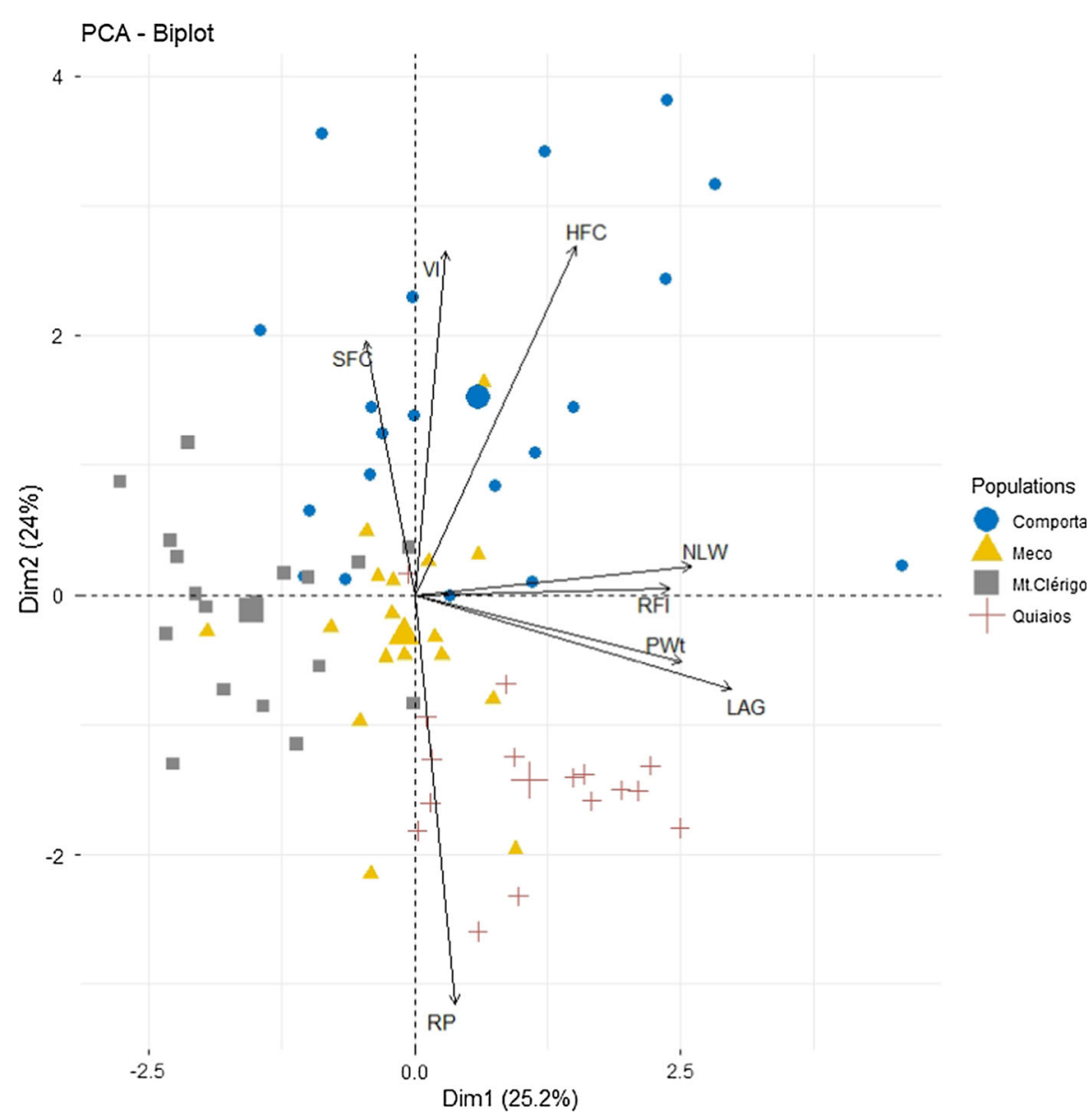

analyses showed three distinct groups (Monte Clérigo, Comporta and Duna de Quiaios), and an overlap of Meco with Monte Clérigo and Comporta. The northern population (Duna de Quiaios) formed a different group from the three southern populations. However, the overlapping between Meco and Monte Clérigo was unexpected, since the population which was geographically closer to Monte Clérigo was that of Comporta. A putative reason to this might be linked to seed dispersers: some studies indicate that one of the main disperser of $C$. album were seagulls (CalviñoCancela 2002, 2004), and their capability to travel long distances could favour gene flow among populations (Calviño-Cancela 2011).

The values of the AMOVA were different from what was observed in other species of the Ericaceae family. Values were higher for within population variance, also using ISSR markers, in Vaccinium myrtillus (Zoratti et al. 2015), Vaccinium angustifolium (Debnath 2009) and Vaccinium vitis-idaea
(Debnath and Sion 2009), probably due to self-pollination capabilities in Vaccinium, in turn, absent in Corema. C. album is cross-pollinated through wind (Álvarez-Cansino et al. 2010; Guitián et al. 1997) and with a low germination percentage (Calviño-Cancela 2004), leading to a higher variation between populations.

The first three axis of the PCA explained $62.1 \%$ of the variation, regarding variability among agro-morphological traits. Although this was not a high percentage, similar results were achieved in other species, regarding morphological traits (Pereira-Lorenzo et al. 2012; Ciarmiello et al. 2015; Kouakou et al. 2018). All four populations partially overlap, Comporta being the population with greater morphological diversity. Monte Clérigo and Quiaios had almost symmetric distribution, even though they slightly overlap.

Comporta had plants with bigger volumes and fruits with bigger sizes. Quiaios had a big influence 


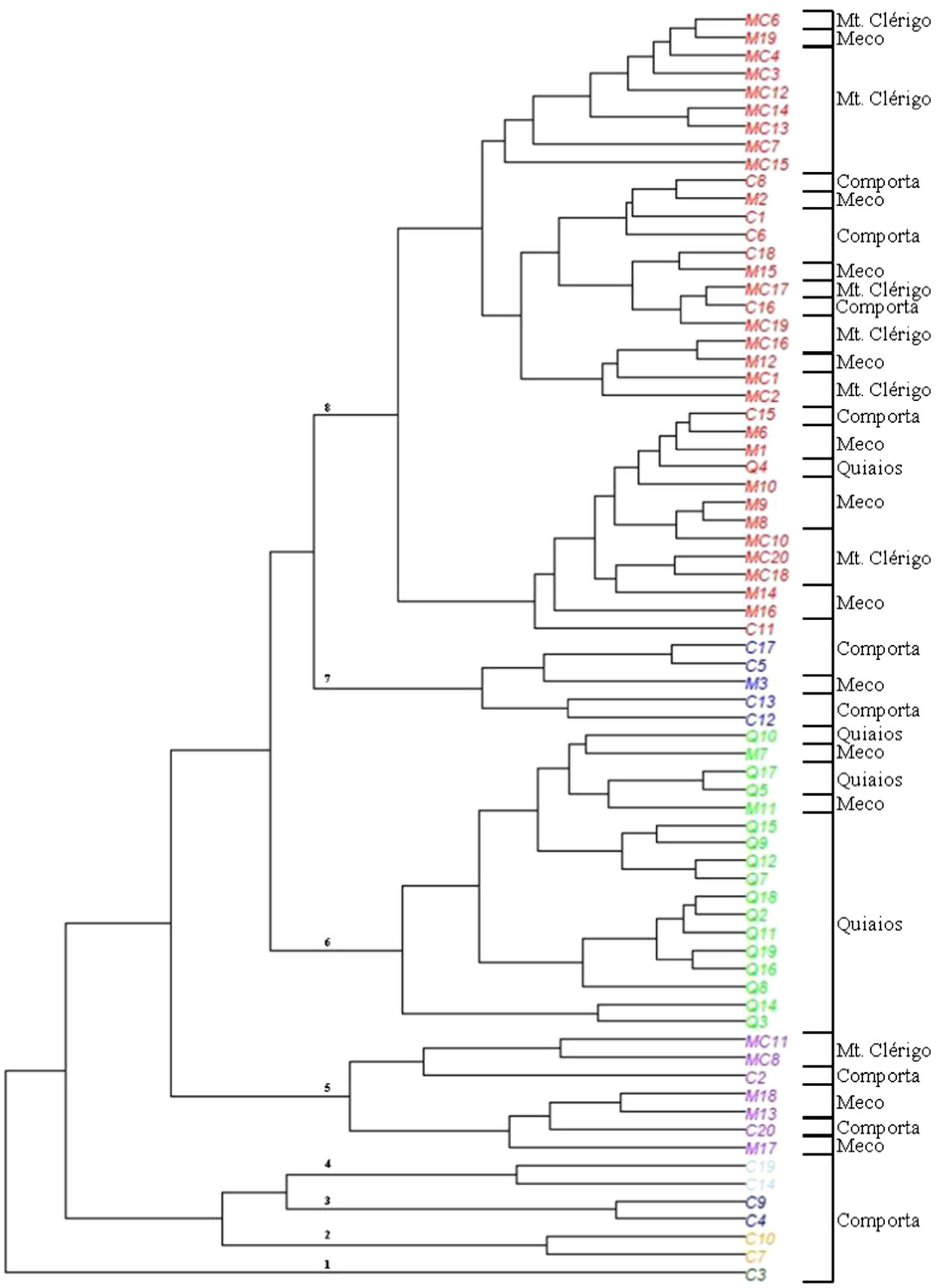


4 Fig. 4 Dendrogram obtained with the UPGMA method using the Mahanalobis distance of the morphological data of the 71 plants. Each colour represents a cluster $(r=0.791)$

regarding the ratio between dry/fresh fruit weight and the length of annual vegetative growth.

The cluster analysis of morphological traits revealed no distinct separation among the C. album genotypes growing in different geographic areas. This variability within and among populations was also found in other studies (Burgos et al. 2018). The morphological traits of the species did not show any accordance to its geographical distribution as, per example, Solouki et al. (2008) found in Matricaria chamomila.

The Mantel test between morphological and molecular data yielded a quite low correlation value, similarly to other studies (Fanizza et al. 1999; Allel et al. 2017; Giordani et al. 2017; Burgos et al. 2018). Several factors might justify the somewhat unexpected low correlation. Molecular markers could be covering parts of the genome with coding and noncoding regions and could be less subjected to selection pressures compared to morphological traits (Burgos et al. 2018; Semagn 2002). A correlation of morphological traits with environmental conditions, but with no genetic correspondence, could mean distinct phenotypes that are not distinct genotypes (Johns et al. 1997). Such discordance might relate to evolutionary and biogeographical processes that are way off the aims the current analysis (see also Martins et al. 2006).

\section{Conclusion}

The analyses provided by the ISSR makers, assembled the accessions regarding their geographical distribution, but most importantly, genetic diversity was found. Genetic diversity was higher between populations and lower within. The morphological traits, showed high morphological diversity, but no signal regarding geographic localization. The Mantel test between genetic and morphological data had a low correlation. Comporta and Meco had higher molecular and morphological diversity, being the chosen populations for future plant material selection.

As the first approach, to our knowledge, to genetic and morphological diversity characterization of $C$. album in Portugal the study reveals a high degree of diversity among the accessions which can be further used for crop improvement. This may provide an opportunity to enhance and boost the breeding strategy.

Acknowledgements The authors are thankful to Francisco Barreto and Francisco Luz for the technical assistance in the field work. This research was funded by the Operational Group "CompetitiveSouthBerries" (Partnership no. 21/Initiative no. 29/PDR2020-101-031721) which was co-financed by the PDR2020, Portugal 2020 and the European Commission.

\section{Compliance with ethical standards}

Conflict of interest The author declares that they have no conflict of interest

\section{References}

Agarwal M, Shrivastava N, Padh H (2008) Advances in molecular marker techniques and their applications in plant sciences. Plant Cell Rep 27(4):617-631. https://doi.org/10. 1007/s00299-008-0507-z

Allel D, Ben-Amar A, Lamine M, Abdelly C (2017) Relationships and genetic structure of North African barley (Hordeum vulgare L.) germplasm revealed by morphological and molecular markers: biogeographical considerations. S Afr J Bot 112:1-10. https://doi.org/10.1016/j.sajb.2017. 05.005

Álvarez-Cansino L, Zunzunegui M, Díaz Barradas MC, Esquivias MP (2010) Gender-specific costs of reproduction on vegetative growth and physiological performance in the dioecious shrub Corema album. Ann Bot 106(6):989-998. https://doi.org/10.1093/aob/mcq197

An D, Bykova NV, Debnath SC (2015) EST-PCR, EST-SSR and ISSR markers to identify a set of wild cranberries and evaluate their relationships. Can J Plant Sci 95(6):1155-1165. https://doi.org/10.4141/cjps-2015-158

Andrade SC, Gonçalves F, Guiné R (2017a) Contribution for the physical-chemical characterization of Portuguese Crowberry (Corema album). Int J Food Sci Nutr 2(4):9-14

Andrade SC, Guiné RP, Gonçalves FJ (2017b) Evaluation of phenolic compounds, antioxidant activity and bioaccessibility in white crowberry (Corema album). J Food Measur Charact 11(4):1936-1946. https://doi.org/10.1007/s11694017-9576-4

Burgos E, Thompson C, Giordano M, Tomas MA (2018) Prebreeding studies in Panicum coloratum var. coloratum: characterization using agro-morphological traits and molecular markers. Trop Grassl Forrajes Trop 6(2):82-92

Calviño-Cancela M (2002) Spatial patterns of seed dispersal and seedling recruitment in Corema album (Empetraceae): the importance of unspecialized dispersers for regeneration. J Ecol 90(5):775-784. https://doi.org/10.1046/j.13652745.2002.00711.x 
Calviño-Cancela M (2004) Ingestion and dispersal: direct and indirect effects of frugivores on seed viability and germination of Corema album (Empetraceae). Acta Oecol 26(1):55-64. https://doi.org/10.1016/j.actao.2004.03.006

Calviño-Cancela M (2011) Gulls (Laridae) as frugivores and seed dispersers. Plant Ecol 212(7):1149-1157. https://doi. org/10.1007/s11258-011-9894-2

Ciarmiello LF, Piccirillo P, Carillo P, De Luca A, Woodrow P (2015) Determination of the genetic relatedness of fig (Ficus carica L.) accessions using RAPD fingerprint and their agro-morphological characterization. S Afr J Bot 97:40-47. https://doi.org/10.1016/j.sajb.2014.11.012

De Mendiburu F (2019) Agricolae: statistical procedures for agricultural research. $\mathrm{R}$ package version, 1.3-1

Debnath SC (2007) Inter simple sequence repeat (ISSR) to assess genetic diversity within a collection of wild lingonberry (Vaccinium vitis-idaea L.) clones. Can J Plant Sci 87(2):337-344. https://doi.org/10.4141/P06-059

Debnath SC (2009) Development of ISSR markers for genetic diversity studies in Vaccinium angustifolium. Nord J Bot 27(2):141-148. https://doi.org/10.1111/j.1756-1051.2009. 00402.x

Debnath SC, Sion M (2009) Genetic diversity, antioxidant activities, and anthocyanin contents in lingonberry. Int $\mathrm{J}$ Fruit Sci 9(2):185-199. https://doi.org/10.1080/ 15538360903005061

D’Orazio M, D’Orazio MM (2019) Package 'StatMatch'. Statistical matching or data fusion, version 1.3.0

Fanizza G, Colonna G, Resta P, Ferrara G (1999) The effect of the number of RAPD markers on the evaluation of genotypic distances in Vitis vinifera. Euphytica 107(1):45-50. https://doi.org/10.1023/A:1003535916622

Gawroński J, Kaczmarska E, Dyduch-Siemińska M (2017) Assessment of genetic diversity between Vaccinium corymbosum L. cultivars using RAPD and ISSR markers. Acta Sci Polonorum Hortorum Cultiv 16(3):129-140

Giordani E, Müller M, Gambineri F, Paffetti D, Arena M, Radice S (2017) Genetic and morphological analysis of Berberis microphylla G. Forst. accessions in southern Tierra del Fuego. Plant Biosyst An Int J Deal Asp Plant Biol 151(4):715-728. https://doi.org/10.1080/11263504. 2016.1211194

Guitián P, Medrano M, Rodríguez M (1997) Reproductive biology of Corema album (L.) D. Don (Empetraceae) in the northwest Iberian Peninsula. Acta Bot Gall 144(1):119-128. https://doi.org/10.1080/12538078.1997. 10515759

Harrell Jr FE (2014) Hmisc package version 4.1-1

Johns MA, Skroch PW, Nienhuis J, Hinrichsen P, Bascur G, Munoz-Schick C (1997) Gene pool classification of common bean landraces from Chile based on RAPD and morphological data. Crop Sci 37(2):605-613. https://doi. org/10.2135/cropsci1997.0011183X003700020049x

Kassambara A, Mundt F (2017) Factoextra: extract and visualize the results of multivariate data analyses. $R$ package version 1.0. 4. 2017

Kouakou CK, Konan AD, N'Da Adopo AA, N'Da HA, Djaha A, Minhibo MY, Djidji MY, Dosso M, N'Guessan AEB (2018) Agro-morphological characterization of cashew (Anacardium occidentale L.) ecotypes from North-Central of Côte d'Ivoire. Fruits 73(5):1
León-González AJ, Truchado P, Tomás-Barberán FA, LópezLázaro M, Barradas MCD, Martín-Cordero C (2013) Phenolic acids, flavonols and anthocyanins in Corema album (L.) D. Don berries. J Food Comp Anal 29(1):58-63. https://doi.org/10.1016/j.jfca.2012.10.003

Martins SR, Vences FJ, de Miera LS, Barroso MR, Carnide V (2006) RAPD analysis of genetic diversity among and within Portuguese landraces of common white bean (Phaseolus vulgaris L.). Sci Hortic 108(2):133-142. https://doi.org/10.1111/plb.12584

Nei M, Li WH (1979) Mathematical model for studying genetic variation in terms of restriction endonucleases. Proc Natl Acad Sci 76(10):5269-5273. https://doi.org/10.1073/pnas. 76.10 .5269

Nóbrega F, Evaristo I, Lisboa A, Valdiviesso T, Trindade CS, Oliveira PB (2016) Abordagens moleculares para o estabelecimento da Corema album como nova cultura. V Colóquio Nacional da Produção de Pequenos Frutos 26:107

Oksanen J, Blanchet FG, Kindt R et al (2013) Package 'vegan'. Community Ecol Pack 2(9):1

Oliveira PB, Dale A (2012) Corema album (L.) D. Don, the white crowberry: a new crop. J Berry Res 2:123-133. https://doi.org/10.3233/JBR-2012-033

Paradis E, Potts A, Schliep K, Winter D (2018) Pegas: population and evolutionary genetics analysis system. Bioinformatics 26:419-420

Pereira-Lorenzo S, dos Santos ARF, Ramos-Cabrer AM, Sau F, Díaz-Hernández MB (2012) Morphological variation in local pears from north-western Spain. Sci Hortic 138:176-182

Powell W, Morgante M, Ander C, Hanafey M, Vogel J, Tingy S, Rafalaski A (1996) The comparison of RFLP, RAPD, AFLP and SSR (microsatellite) marker for germplasm analysis. Mol Breed 2:225-238. https://doi.org/10.1007/ BF00564200

Prevost A, Wilkinson MJ (1999) A new system of comparing PCR primers applied to ISSR fingerprinting of potato cultivars. Theor Appl Genet 98:107-112. https://doi.org/ 10.1007/s001220051046

R Core Team. R: A language and environment for statistical computing (2013) R foundation for statistical computing, Vienna, Austria. ISBN 3-900051-07-0. http://www.Rproject.org/

Reddy MP, Sarla N, Siddiq EA (2002) Inter simple sequence repeat (ISSR) polymorphism and its application in plant breeding. Euphytica 128(1):9-17. https://doi.org/10.1023/ A:1020691618797

Roldán-Ruiz I, Dendauw J, Van Bockstaele E, Depicker A, De Loose M (2000) AFLP markers reveal high polymorphic rates in ryegrasses (Lolium spp.). Mol Breed 6:125-134. https://doi.org/10.1023/A:1009680614564

Semagn K (2002) Genetic relationships among ten endod types as revealed by a combination of morphological, RAPD and AFLP markers. Hereditas 137(2):149-156. https://doi.org/ 10.1034/j.1601-5223.2002.01600.x

Solouki M, Mehdikhani H, Zeinali H, Emamjomeh AA (2008) Study of genetic diversity in Chamomile (Matricaria chamomilla) based on morphological traits and molecular markers. Sci Hortic 117(3):281-287. https://doi.org/10. 1016/j.scienta.2008.03.029 
Ueno S, Rodrigues JF, Alves-Pereira A, Pansarin ER, Veasey EA (2015) Genetic variability within and among populations of an invasive, exotic orchid. AoB Plants. https://doi. org/10.1093/aobpla/plv077

Yakimowski SB, Eckert CG (2008) Populations do not become less genetically diverse or more differentiated towards the northern limit of the geographical range in clonal Vaccinium stamineum (Ericaceae). New Phytol 180(2):534-544. https://doi.org/10.1111/j.1469-8137. 2008.02582. $\mathrm{x}$

Zietkiewicz E, Rafalski A, Labuda D (1994) Genome fingerprinting by simple sequence repeat (SSR)-anchored polymerase chain reaction amplification. Genomics 20(2):176-183. https://doi.org/10.1006/geno.1994.1151
Zoratti L, Palmieri L, Jaakola L, Häggman H (2015) Genetic diversity and population structure of an important wild berry crop. AoB Plants. https://doi.org/10.1093/aobpla/ plv117

Zunzunegui M, Díaz-Barradas MC, Clavijo A, Álvarez-Cansino L, Ain Lhout F, García Novo F (2006) Ecophysiology, growth timing and reproductive effort of three sexual forms of Corema album (Empetraceae). Plant Ecol 183:35-46. https://doi.org/10.1007/s11258-005-9004-4

Publisher's Note Springer Nature remains neutral with regard to jurisdictional claims in published maps and institutional affiliations. 